\title{
Młodzi dorośli Polacy wobec redystrybucji dóbr używanych
}

\section{Young adult Poles toward the redistribution of second-hand goods}

\author{
dr Agnieszka Wilczak \\ Uniwersytet Warszawski, Wydział Zarządzania, Katedra Marketingu \\ ORCID 0000-0002-1594-3090 \\ e-mail: awilczak@wz.uw.edu.pl
}

\begin{abstract}
Artykuł poświęcono analizie postaw młodych dorosłych Polaków wobec kupowania i używania rzeczy uprzednio stanowiących własność innych klientów. Na podstawie studiów literaturowych i wyników badań jakościowych skonstruowano skalę, za pomocą której dokonano pomiaru gotowości do udziału w gospodarce opartej na redystrybucji dóbr używanych. Na podstawie danych ilościowych wyodrębniono grupy różniące się poziomem gotowości. Zbadano również zależność między kupowaniem i używaniem produktów second-hand a zmiennymi demograficznymi, dowodząc istnienia zależności między takimi zachowaniami a płcią oraz braku istotnej statystycznie zależności między pozostałymi zmiennymi. Ustalono, które kategorie dóbr second-hand są kupowane najczęściej przez kobiety i mężczyzn. Na podstawie odpowiedzi na pytania otwarte udzielonych przez respondentów przeprowadzono analizę systematyczną oraz jakościową analizę treści, dzięki czemu zidentyfikowano kluczowe korzyści płynące z kupowania i użytkowania produktów second-hand oraz bariery sprawiające, że młodzi dorośli Polacy nie kupują i nie użytkują dóbr second-hand.
\end{abstract}

Keywords

dekonsumpcja, gospodarka zamkniętego obiegu, produkty używane, redystrybucja

The article is devoted to an analysis of young adult Poles' attitude towards buying and using second hand goods. A scale based on literature studies and qualitative research was constructed and used to measure the readiness to participate in an economy founded on the redistribution of used goods. Groups of different readiness-level were formed on the grounds of quantitative data. Also, the correlation between buying and using SH goods and demographic variables was analysed, proving the existence of a dependence of such behaviours and genders as well as a lack of a statistically relatable correlation between remaining variables. The most-bought SH goods categories among women and men were assessed. A systematic analysis was conducted based on the answers from openended questions given by the respondents as well as a qualitative analysis of content which led to the identification of key benefits coming from buying and using SH products and the barriers preventing young adult Poles from buying and using SH goods.

\section{Slowa kluczowe}

deconsumption, circular economy, second-hand goods, redistribution

JEL: M30, M31

Str. 16-30

\section{Bibliografia}

Camacho-Otero, J., Boks, C. i Pettersen, I. (2018). Consumption in the circular economy: a literature review. Sustainability, 10(8). https://doi.org/10.3390/su10082758

Castellani, V., Sala, S. i Mirabella, N. (2014). Beyond the throwaway society: A life cycle-based assessment of the environmental benefit of reuse. Integrated Environmental Assessment and Management, 11(3), 373-382. https://doi.org/10.1002/ieam.1614 
Clausen, J., Blattel-Mink, B., Erdmann, L. i Henseling, C. (2010). Contribution of online trading of used goods to resource efficiency: An empirical study of eBay users. Sustainability, 2(6), 1810-1830. https://doi.org/10.3390/su2061810

Edbring, E., Lehner, M. i Mont, O. (2016). Exploring consumer attitudes to alternative models of consumption: Motivations and barriers. Journal of Cleaner Production, 123, 5-15. https://doi.org/10.1016/j.jclepro.2015.10.107

Ferraro, C., Sands, S. i Brace-Govan, J. (2016). The role of fashionability in second-hand shopping motivations. Journal of Retailing and Consumer Services, 32, 262-268. https://doi.org/10.1016/j.jretconser.2016.07.006

Guiot, D. i Roux, D. (2008). Measuring second-hand shopping motives, antecedents, consequences. Recherche et Applications en Marketing, 23, 63-94. https://doi.org/10.1177/205157070802300404

Guiot, D. i Roux, D. (2010). A second-hand shoppers' motivation scale: Antecedents, consequences, and implications for retailers. Journal of Retailing, 86(4), 383-399. https://doi.org/10.1016/j.jretai.2010.08002

Kirchherr, J., Reike, D. i Hekkert, M. (2017). Conceptualizing the circular economy: An analysis of 114 definitions. Resources, Conservation and Recycling, 127, 221-232. https://doi.org/10.1016/j.resconrec.2017.09.005

Heath, M. T. i Chatzidakis, A. (2012). „Blame it on marketing”: Consumers' views on unsustainable consumption. International Journal of Consumer Studies, 36(6), 656-667. https://doi.org/10.1111/j.1470-6431.2011.01043.x

Paraquel, B., Lunardo, R. i Benoit-Moreau, F. (2017). Sustainability of the sharing economy in question: When second-hand peer-to-peer platforms stimulate indulgent consumption. Techonological Forecasting \& Social Change, 125, 48-57. https://doi.org/10.1016/j.techfore.2017.03.029

Pietruszka, S. (2016). Portrety psychologiczne klientów sklepów z taniq odzieża na przykładzie Polski, 214-217. Pozyskano z http://www.repozytorium.uph.edu.pl (17.11.2017).

Rybkowska, A. (2017). Zachowania konsumentów na rynku second-hand. Marketing i Zarzadzanie, (2), 95-104.

Sandin, G. i Peters, G. M. (2018). Environmental impact of textile reuse and recycling - A review. Journal of Cleaner Production, 184, 353-365. https://doi.org/10.1016/j.jclepro.2018.02.266

Smolarek, M. (2013). Kupowanie i wyrzucanie, składowanie i kolekcjonowanie, ponowne wykorzystywanie przedmiotów współczesne tendencje wśród zachowań konsumenckich. Kultura i Społeczeństwo, (4), 69-82. https://doi.org/ 10.2478/kultura-2014-0004

Steffen, A. (2017). Second-hand consumption as a lifestyle choice. Materiały konferencyjne z: The International Conference on Consumer Research (ICCR). Düsseldorf.

Turunen, L. L. M. i Leipamaa-Leskinen, H. (2015). Pre-loved luxury: Identifying the meaning of second-hand possessions. Journal of Product and Brand Management, 24(1), 57-65. https://doi.org/10.1108/JPBM-05-2014-0603

Wilczak, A. (2016). Rola konsumenta w procesie kreowania wartości opartej na zasadzie 5R. Problemy Zarzadzania, 14(1), 87-99. https://doi.org/10.7172/1644-9584.58.6

Williams, C. C. i Paddock, C. (2003). The meaning of alternative consumption practices. Cities, 20, 311-319. https://doi.org/ $10.1016 /$ S0264-2751(03)00048-9

Williams, C. C i Windebank, J. (2002). The „excluded consumer”: A neglected aspect of social exclusion? Policy and Politics, 30(4), 501-513. https://doi.org/10.1332/030557302760590422 